\title{
ASSOCIATION OF GSTT1 AND GSTM1 GENE POLYMORPHISMS WITH SUSCEPTIBILITY TO AUTOIMMUNE DISEASES: A PRELIMINARY STUDY
}

\author{
Darko V. Grujičić1 ${ }^{*}$, Marina Z. Radović Jakovljević1 ${ }^{1}$, Olgica B. Mihaljević ${ }^{\text {, }}$ \\ Snežana T. Živančević-Simonović ${ }^{2}$ Olivera M. Milošević-Djordjević ${ }^{1,3}$ \\ ${ }^{1}$ University of Kragujevac, Serbia, Faculty of Science, Department of Biology and Ecology, \\ Radoja Domanovića 12, 34000 Kragujevac, Serbia \\ ${ }^{2}$ University of Kragujevac, Serbia, Faculty of Medical Sciences, \\ Department of Pathophysiology, Svetozara Markovića 69, 34000 Kragujevac, Serbia \\ ${ }^{3}$ University of Kragujevac, Serbia, Faculty of Medical Sciences, Department of Genetics, \\ Svetozara Markovića 69, 34000 Kragujevac, Serbia \\ *Corresponding author; E-mail: darko@kg.ac.rs
}

(Received March 1st, 2018; Accepted May 9th, 2018)

\begin{abstract}
Autoimmune diseases (ADs) are chronic conditions initiated by the loss of immunological tolerance to self-antigens. The aim of this study was to detrmine how polymorphisms of glutathione S-transferases T1 and M1 (GSTT1 and GSTM1) genes influences on the occurrence of two autoimmune diseases: multiple sclerosis (MS) and Hashimoto's thyroditis (HT). A multiplex polymerase chain reaction (PCR) was used to detect the deletions in GSTT1 and GSTM1 genes. Our results showed that patients with ADs had significantly higher ( $\mathrm{p}<0.05$ ) frequency of GSTM1 null genotype compared to controls ( $44.4 \%$ vs. $0.0 \%$, respectively). However, the homozygous deletion of both analyzed genes (GSTT1 null/GSTM1 null) showed no significant differences between these genotypes in the patients and controls $(11.1 \%$ vs $0.0 \%$, respectively). Our results showed that observed differences in the distribution of GSTT1 and GSTM1 null genotype in patients depending on the diagnosis (MS or HT) when compared to the same frequency of genotypes in control, were not statistically significant $(p>0.05)$. This study suggests the potential role of GSTM1 deletion on ADs susceptibility, but on the other hand this study should be repeated in other patients with the same or similar diagnosis of ADs.
\end{abstract}

Keywords: polymorphisms of GSTT1 and GSTM1 genes, multiplex polymerase chain reaction, multiple sclerosis, Hashimoto's thyroditis.

\section{INTRODUCTION}

Autoimmune diseases (ADs) are chronic conditions initiated by the loss of immunological tolerance to self-antigens (TODOROVIĆ-ĐILAS et al., 2011). It is a heterogeneous group of disorders in which multiple changes in the immune system can be specific to a particular tissue or organ or may be systemic, non-specific, involving multiple tissues or organs (RAY et al., 2012). Literary data indicate that more than 80 clinically 
different diseases have been identified, including multiple sclerosis (MS) and Hashimoto's thyroiditis (HT) (ANTONIOU et al., 2010).

MS is a demyelinating, inflammatory disease of central nervous system (CNS) that affects young adults (LEE et al., 2015). HT is characterized by lymphocytic infiltration that leads to disruption of the tissue architecture of the thyroid gland, resulting in a progressive loss of thyroid function (ACHARYA et al., 2014). It is one of most frequent ADs responsibile causes of morbidity in women, with four females and one male person in 1,000 inhabitants a year diagnosed with autoimmune thyroid inflamation (ĐURICA and VUKSANOVIĆ, 2005; GERENOVA and GADJEVA, 2007).

ADs have a multifactorial etiology, so the underlying factors in the development of autoimmunity are genes of susceptibility such as human leucocyte antigen (HLA) genes that affect the loss of tolerance (GoUGH and SimMONDS, 2007). The environmental factors that can trigger autoreactive lymphocytes are infections (PENDER and GREER, 2007), exposure to chemicals, xenobiotics, toxins, or stress (ERMANN and FATHMAN, 2001; RIEGER and GERSHWIN, 2007).

Numerous studies reported that oxidative stress (OS) play a mayor role in pathophysiology of various diseases, including ADs (WEST, 2000; CILENŠEK et al., 2012; ADAMCZYK et al., 2017). OS is the result of an imbalance between the amount of reactive oxygen species (ROS) and the capacity of antioxidant defence systems (ALLEN and TRESINI, 2000). Glutathione S-transferases (GSTs) are a family detoxifications enzymes that are essential for the biotransformation of xenobiotics and carcinogens as well as cell protection against OS. The products of GSTT1 and GSTM1 genes are enzymes glutathione Stransferases $\mathrm{T} 1$ and M1, which carry out important detoxificatious processes of xenobiotics in organism. Homozygous deletion of these genes (null genotype) results in the total absence of enzymatic activity and leads to an inability of xenobiotics elimination from organisms, it accumulates and manifest their harmful effects (GARTE et al., 2001).

Considering that oxidative damages to biomolecules increased the risk of ADs as well as that GST enzymes are the main endogenous antioxidant protection system in eliminations of free radicals, the aim of this study was to examine the association of GSTT1 and GSTM1 polymorphisms influences on the occurrence of both diseases, MS and HT.

\section{MATERIALS AND METHODS}

\section{Patients}

Polymorphisms of GSTT1 and GSTM1 genes was analysed in 18 persons: eight patients of ADs and eight healthy individuals who presented control sample. In sample ADs patients it was four patients with MS and five patients with HT diagnosis, mean age

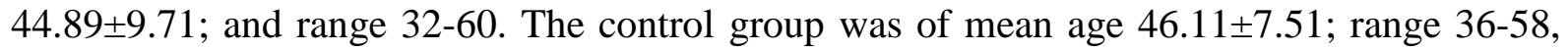
without past histories of neurodegenerative disorders. The study was approved by Ethical Committee of the Clinical Centre Kragujevac. All patients and control subjects gave written informed consent according to the Helsinki Declaration.

\section{Genomic DNA isolation and genotype analysis of GSTT1 and GSTM1 polymorphisms}

Genomic DNA from whole peripheral blood was extracted automatically by Biorobot EZ1. After that, the concentration of DNA in each sample was calculated by biphotometer (Eppendorf, Hamburg, Germany), and polymerase chain reaction, PCR (Eppendorf, 
Hamburg, Germany) was carried out. Visualization of amplified products was achieved by electrophoresis on $2 \%$ agarose gel.

Genomic DNA was isolated from $350 \mu \mathrm{l}$ of whole peripheral blood using automatically a Biorobot the EZ1 DNA Blood $350 \mu \mathrm{l}$ Kit (Qiagen, Hilden, Germany) and BioRobot EZ1 (Qiagen, Hilden, Germany), following the manufacturer's instructions.

To determine the GSTT1 and GSTM1 genotypes a multiplex PCR method was carried simultaneously, as described in ABDEL-RAHMAN et al. (1996) with little modifications. In 50 $\mu \mathrm{l}$ PCR reaction mix containing $30 \mathrm{pmol}$ of each of primers (GSTT1, GSTM1 and CYP1A1, Invitrogen, California, USA), $200 \mu \mathrm{M}$ of each deoxynucleotide triphosphate (Invitrogen, California, USA), $1.5 \mathrm{mM}$ of $\mathrm{MgCl}_{2}, 1 \mathrm{X}$ PCR buffer, two units of Taq polymerase (Invitrogen, California, USA), 5\% dimethyl sulfoxide (DMSO), 5\% glycerol, $50 \mathrm{ng}$ of template DNA was amplified. PCR cycles consisted of an initial denaturation at $94^{\circ} \mathrm{C}$ for 5 minutes, 35 cycles of denaturation at $94^{\circ} \mathrm{C}$ for 2 minutes, annealing for 1 minute at $58^{\circ} \mathrm{C}$ and extension at $72^{\circ} \mathrm{C}$ for 1 minute, followed by a final extension step for 10 minutes at $72^{\circ} \mathrm{C}$, were performed, after initiative denaturation at $94^{\circ} \mathrm{C}$ for 5 minutes.

PCR products were separated and analyzed on $2 \%$ agarose gel stained with SYBER Safe DNA gel stain (Invitrogen, California, USA). The presence of $480 \mathrm{bp}$ band corresponds to GSTT1 positive genotype while 215 bp band corresponds to GSTM1 positive genotype. The band of internal control CYP1A1 (312 bp) was always present (Table 1).

Table 1. Primers for PCR (oligonucleotide sequences used for amplifications and detection GSTT1 and GSTM1 polymorphisms).

\begin{tabular}{lllc}
\hline Gene & Primer & Sequence (5'-3') & $\begin{array}{c}\text { PCR } \\
\text { product size/bp }\end{array}$ \\
\hline \multirow{2}{*}{ GSTT1 } & $\begin{array}{l}\text { forward } \\
\text { reverse }\end{array}$ & $\begin{array}{l}\text { TTCCTTACTGGTCCTCACATCTC } \\
\text { TCACCGGATCATGGCCAGCA }\end{array}$ & 480 \\
\multirow{2}{*}{ GSTM1 } & forward & GAACTCCCTGAAAAGCTAAAGC & 215 \\
& reverse & GTTGGGCTCAAATATACGGTGG & \\
\multirow{2}{*}{ CYP1A1 } & forward & GAACTGCCACTTCAGCTGTCT & 312 \\
& reverse & CAGCTGCATTTGGAAGTGCTC & \\
\hline
\end{tabular}

\section{Statistical analysis}

The data are expressed as mean \pm standard error (SE). Statistical significance was determined using the Chi-square $\left(\chi^{2}\right)$ test. A $p<0.05$ was considered significant. The magnitude of correlation between variables was done using a SPSS (Chicago, IL) statistical software package (IBM SPSS Statistics 20).

\section{RESULTS}

The results of GST polymorphism analyses in the patients with ADs are presented in Table 2 and 3, and Figure 1.

Table 2 shows distribution of GSTT1 and GSTM1 polymorphism, alone or in combinations in patients with ADs, and in the healthy control. The obtained results indicate that the difference in the distribution of GSTT1 null genotype between ADs patients and 
control is pretty similar ( $11.1 \%$ vs. $0.0 \%$, respectively), so that the observed difference in distribution of this genotype was not statistically significant ( $p>0.05)$. Results distribution of deletion polymorphism GSTT1 and GSTM1 gene indicates the significant frequency of GSTM1 null genotype in patients with ADs, in comparison with the control (44.4\% vs. 0.0\%, respectively) and that the observed difference is statistically significant ( $\mathrm{p}<0.05)$. The results analyses of the combined genotypes indicate that GSTT1 positive/GSTM1null genotype is slightly less, as compared to the distribution of genotype GSTT1 positive/GSTM1 positive (33.3\% vs. $55.6 \%$, respectively), but the observed difference in distribution of this genotypes was not statistically significant $(\mathrm{p}>0.05)$.

Table 2. Distrubution of GSTT1 and GSTM1 genotypes in patients with autoimmune diseases and in control sample.

\begin{tabular}{|c|c|c|c|}
\hline Polymorphisms & Patients (\%) & Controls (\%) & $\mathbf{p}$ \\
\hline \multicolumn{4}{|l|}{ GSTT1 } \\
\hline positive & $8(88.9)$ & $9(100 \%)$ & \multirow{2}{*}{$\chi^{2}=1.059, \mathrm{p}>0.05$} \\
\hline null & $1(11.1)$ & $0(0.0 \%)$ & \\
\hline \multicolumn{4}{|l|}{ GSTM1 } \\
\hline positive & $5(55.6)$ & $9(100 \%)$ & \multirow[t]{2}{*}{$\chi^{2}=5.143, \mathrm{p}<0.05^{*}$} \\
\hline null & $4(44.4)$ & $0(0.0 \%)$ & \\
\hline \multicolumn{4}{|l|}{ GSTT1/ GSTM1 } \\
\hline positive/positive & $5(55.6)$ & $9(100 \%)$ & \multirow{4}{*}{$\chi^{2}=5.143, p>0.05$} \\
\hline positive/null & $3(33.3)$ & $0(0.0 \%)$ & \\
\hline null/positive & $0(0.0 \%)$ & $0(0.0 \%)$ & \\
\hline null/null & $1(11.1)$ & $0(0.0 \%)$ & \\
\hline
\end{tabular}

Reference group is GSTT1/GSTM1 positive/positive genotype;

* statistically significant difference

Table 3. Distribution of GSTT1 and GSTM1 genotypes in patients depending on the diagnosis of autoimmune disease and in control sample.

\begin{tabular}{rcccc}
\hline \multirow{2}{*}{ Polymorphisms } & \multicolumn{2}{c}{ Patients } & Controls (\%) & p \\
& multiplex (\%) & $\begin{array}{c}\text { Hashimoto's } \\
\text { thyroiditis (\%) }\end{array}$ & & \\
\hline \multicolumn{1}{|c}{ GSTT1 } & & & & \\
positive & $4(100 \%)$ & $4(80.0 \%)$ & $9(100 \%)$ & $\chi^{2}=2.753 ; \mathrm{p}>0.05$ \\
null & $0(0.0 \%)$ & $1(20.0 \%)$ & $0(0.0 \%)$ & \\
GSTM1 & & & & \\
positive & $2(50.0 \%)$ & $3(60.0 \%)$ & $9(100 \%)$ & $\chi^{2}=5.271 ; \mathrm{p}>0.05$ \\
null & $2(50.0 \%)$ & $2(40.0 \%)$ & $0(0.0 \%)$ & \\
GSTT1/ GSTM1 & & & & \\
positive/positive & $2(50.0 \%)$ & $3(60.0 \%)$ & $9(100 \%)$ & $\chi^{2}=7.971 ; \mathrm{p}>0.05$ \\
positive/null & $2(50.0 \%)$ & $1(20.0 \%)$ & $0(0.0 \%)$ & \\
null/positive & $0(0.0 \%)$ & $0(0.0 \%)$ & $0(0.0 \%)$ & \\
null/null & $0(0.0 \%)$ & $1(20.0 \%)$ & $0(0.0 \%)$ & \\
\hline
\end{tabular}

Table 3 shows the distribution of GSTT1 and GSTM1 polymorphism in patients diagnosed according to the ADs, in comparison to the control sample. Differences in the distribution of GSTT1 null/GSTM1 null genotypes in patients, depending on the diagnosis 
when compared with the control sample, were not statistically significant. Patients diagnosed with HT had a higher frequency of GSTT1 null/GSTM1 null genotypes, compared to the control sample (20.0\% vs. $0.0 \%$, respectively), but with no statistical significance. Those patients were used to observe twice the size GSTT1 null genotype compared to the control sample, but also without statistical significance. In patients who were diagnosed with MS the GSTT1 gene deletions were observed, and regarding the frequency of GSTM1 deletion there was also no statistically significant difference compared to the control sample. In relation to the diagnosis, the distribution of GSTM1 null genotype is almost equally represented.

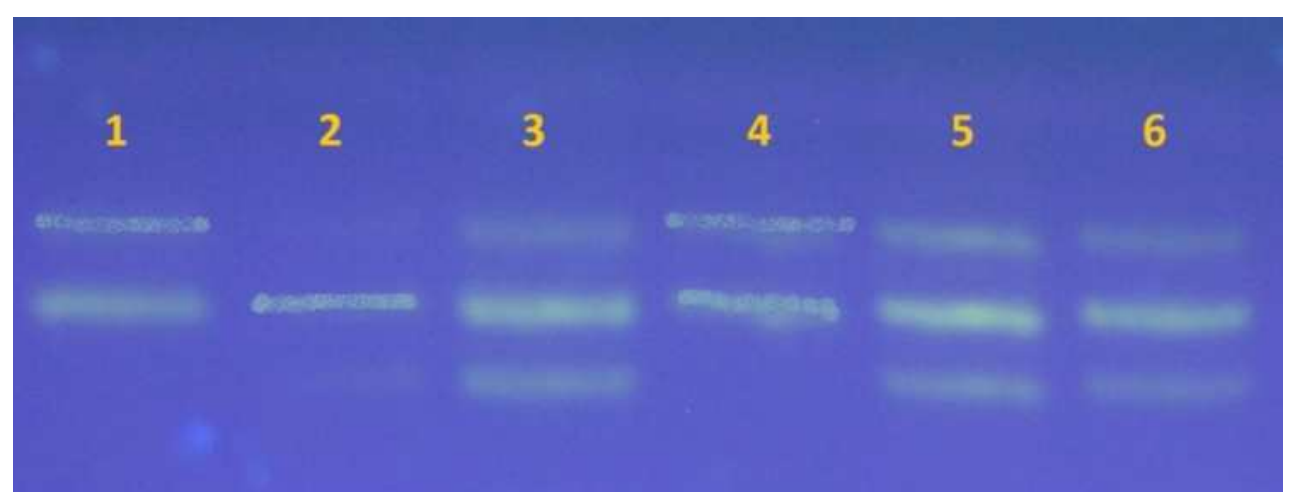

Figure 1. Multiplex PCR products separated and analyzed on $2 \%$ agarose gel:

Lines 1 and 4 patients with GSTT1 positive and GSTM1 null genotypes;

line 2 patient with GSTT1 null and GSTM1 null genotypes;

lines 3, 5 and 6 patients with GSTT1 positive and GSTM1 positive genotypes.

\section{DISCUSSION}

In this preliminary study we investigated the possible influence of GSTT1 and GSTM1 null genotypes on the risk of development ADs. Previous studies have observed that their mutations could associated with different diseases, including cancer (HAQ and HARMER, 2004; CILENŠEK et al., 2012; STOŠIĆ et al., 2014; MiLOŠEVIĆ-DJORDJEVIĆ et al., 2017). What might be important in different diseases is the glutathione S-transferases (GSTs), as the main enzymes of antioxidant defense. The inactivation of toxic endogenous products and xenobiotic agents, the removal of ROS and catalysis of reactions in metabolic pathway beyound the detoxification are some of the roles of the GSTs in cells (SHEENAN et al., 2001; HAYES et al., 2005). A number of studies report that ROS play a key role in myelin phagocytosis, contributing to several of the processes underlying MS pathogenesis (TASSET et al., 2012; FERREIRA et al., 2013; OHL et al., 2016). The impact of GSTs detoxification pathway on complex pathogenesis and heterogeneity of clinical findings in MS, particulary the exact correlation between indicators of clinical severity and different GST genotiypes, has not yet been fully elucidated (BAČIĆ BARONICA et al., 2014).

Several studies have examined associations between GSTT1 and GSTT1 polymorphisms and ADs, but the results reported are contradictory, possibly because of the low statistical power of individual studies (LEE et al., 2015). While some authors suggest that there is an association of GSTT1 and GSTM1 polymorphisms and these diseases (MANN et al., 2000; ŽIVKOVIĆ et al., 2013), other authors indicate that there is no association between them (STAVROPOULOU et al., 2007).

Our results showed that the difference in distribution of GSTT1 null genotype between ADs patients and control sample is quite similar, so the observed difference was not 
statistically significant $(\mathrm{p}>0.05)$ and there is no association between occurance of ADs and deletion of GSTT1 gene. These results were in accordance with results STAVROPOULOU et al. (2007) which investigated polymorphism of these genes in sample of 47 patients with MS (18 males and 29 females), and in the control sample of healthy donors. These authors also showed no significant difference in distribution GSTT1 null genotype between patients $(19.1 \%)$ and control sample (18.8\%).

On the other hand, the results of our study clearly indicate the statistical significantlly difference in distribution of GSTM1 null genotype between ADs patients and control sample ( $44.4 \%$ vs. $0.0 \%$, respectively) which can indicate that exists association between occurance of ADs and deletion of GSTM1 gene. On the contrary to these findings, STAVROPOULOU et al. (2007) showed that there is no significant difference in the distribution of GSTM1 null genotype between patients with MS and the control (53.2\% vs. 38.8\%, respectively). In addition, the same authors found the higher incidence of GSTM1 null genotype observed in female patients, suggests a possible role of the GSTM1 detoxification pathway in a genderdependent manner.

However, the homozygous deletion of both analyzed genes (GSTT1 null/GSTM1 null) showed no significant differences between the genotypes in patients with ADs and control sample ( $11.1 \%$ vs $0.0 \%$, respectively). Statistically significant difference in the distribution of GSTM1 null genotype in the sample of patients in comparison to the control is lost, when analyzing the same polymorphism, giving due consideration to the diagnosis, which can be explained by small sample size. The fact that the GSTT1 and GSTM1 null genotypes were associated with severe disability in patients with a disease duration of more than 10 years, MANN et al. (2000) pointed out that long-term prognosis in MS is influenced by the ability to remove the toxic products of oxidative stress. MANN et al. (2000) showed that the GSTT1 and GSTM1 null genotypes were associated with severe disability in patients with a disease duration of more than 10 years. These results indicate that long-term prognosis in MS is influenced by the ability to remove the toxic products of oxidative stress.

ŽIVKOVIĆ et al. (2013) in recently conducted study have shown that patients with MS have significantly higher frequency of GSTT1 null genotype in relation to the control group ( $37.36 \%$ vs. $21.86 \%$, respectively). This study has shown that there is a significant association between a MS and deletions GSTT1 gene. The same authors also detected the significantly higher frequency of double deletions (GSTM1 null/GSTT1 null) in patients with MS compared to controls.

Our results showed that observed differences in the distribution of GSTT1 and GSTM1 null genotype in patients, depending on the diagnosis (MS or HT) when compared to the same frequency of genotypes in control group, were not statistically significant $(p>0.05)$. In our study the patients with HT had a higher frequency of GSTM1 null genotype compared to the control group ( $20.0 \%$ vs. $0.0 \%$, respectively), but without statistical significance. The same patients were used to observe double higher frequency of GSTM1 null genotype compared to control sample, but also without statistical significance. In patients with MS the deletion of GSTT1 gene was not observed, and there is no statistical significant difference in frequency of GSTM1 deletion compared to contol sample. Recently conducted meta-analysis demonstrates that the GSTT1 null genotype is associated with MS in Caucasian populations (LEE et al., 2015). 


\section{CONCLUSION}

Based on the results of this study we conclude that GSTM1 gene has a importal role in development of ADs. Most likely, this gene affects the incidence of ADs by a reduced or complete dysfunction of encoded enzyme. Future researches of both polymorphisms (GSTT1 and GSTM1) on a larger sample will contibute to a better understanding of their participation in ethiopathology of these diseases. Considering the fact that these diseases are not so rare, future studies should explore not only the role of genotype of both genes (GSTT1 and GSTM1), but also the potential role of other polymorphisms as genetic factors that lead to ADs.

\section{Acknowledgments}

This study was supported by the Ministry of Education, Science and Technological Development of the Republic of Serbia for financial support (Project No. III 41010).

\section{References:}

[1] Abdel-Rahman, S.Z., El-Zein, R.A., Anwar, W.A., Au, W.W. (1996): A multiplex PCR procedure for polymorphic analysis of GSTM1 and GSTT1 genes in population studies. Cancer Letters 107 (2): 229-233.

[2] Acharya, U.R., Sree, S.V., Krishnan, M.M., Molinari, F., Zieleźnik, W., BARDALES, R.H., WitKowsKA, A., SuRI. J.S. (2014): Computer-aided diagnostic system for detection of Hashimoto thyroiditis on ultrasound images from a Polish population. Journal Ultrasound in Medicine 33 (2): 245-253. doi: 10.7863/ultra.33.2.245

[3] AdAmCZYK, B., NiedZIElA, N., AdAMCZYK-SowA, M. (2017): Chapter 10Novel Approaches of Oxidative Stress Mechanisms in the Multiple Sclerosis Pathophysiology and Therapy. In: Zagon, I.S., McLaughlin, P.J. (eds.) Multiple Sclerosis: Perspectives in Treatment and Pathogenesis. Brisbane (AU), Codon Publications.

[4] Allen, A.G., Tresini, M. (2000): Oxidative stress and gene regulation. Free Radical Biology \& Medicine 28 (3): 463-499.

[5] Antoniou, D.I., Georgitsi, M.A., Gkantouna, V.A., Patrinos, G.P., Poulas, K.A., TsaKalidis, A.K., TZIMAS, G.E., VIEnNAS, E.S. (2010): dAUTObase: Mining gems on autoimmune diseases utilizing web visualization technologies. In: Proceedings of the 10th IEEE International Conference on Information Technology and Applications in Biomedicine (ITAB 2010), Nov. 2010, Corfu, Greece, pp. 1-5.

[6] BaČić Baronica, K., Mlinac, K., Petlevski, R., Ozretić, D., Vladić, A., Bognar KAlANJ, S., ŽUnTAR, I. (2014): Progression of multiple sclerosis is associated with gender differences in glutathione S-transferase P1 detoxification pathway. Acta Neurobiologiae Experimentalis 74 (3): 257-265.

[7] Cilenšek, I., Mankoč, S., Globočnik Petrovič, M., Petrovič, D. (2012): GSTT1 null genotype is a risk factor for diabetic retinopathy in Caucasians with type 2 diabetes, whereas GSTM1 null genotype might confer protection against retinopathy. Disease Markers 32 (2): 93-99. doi: 10.3233/DMA-2011-0863 
[8] Todorović-Đilas, Lj., IČIn, T., Novaković-Paro, J., Bajkin, I. (2011): Autoimuna bolest štitaste žlezde i druge neendokrinološke autoimune bolesti. Medicinski Pregled 64 (3-4): 183-187. doi: 10.2298/MPNS1104183T [in Serbian with English summary]

[9] ĐuriCA, S., VuKSANOvić, M. (2005): Autoimunska bolest tireoideje. Medicinski glasnik 38: $39-48$.

[10] ERmann, J., FAthman, C.G. (2001): Autoimmune diseases: genes, bugs and failed regulation. Nature Immunology 2: 759-761.

[11] Ferreira, B., Mendes, F., Osório, N., Caseiro, A., Gabriel, A., Valado, A. (2013): Glutathione in multiple sclerosis. British Journal of Biomedical Science 70 (2):75-79. doi: 10.1080/09674845.2013.11669939

[12] Garte, S., Gaspari, L., Alexandrie, A.K., Ambrosone, C., Autrup, H., Autrup, J.L., Baranova, H., Bathum, L., Benhamou, S., Boffetta, P., Bouchardy, C., Breskvar, K., Brockmoller, J., Cascorbi, I., Clapper, M.L., Coutelle, C., Daly, A., Dell'omo, M., Dolzan, V., Dresler, C.M., Fryer, A., Haugen, A., Hein, D.W., Hildesheim, A., Hirvonen, A., Hsieh, L.L., Ingelman-Sundberg, M., Kalina, I., Kang, D., Kihara, M., Kiyohara, C., Kremers, P., Lazarus, P., Le Marchand, L., Lechner, M.C., Van Lieshout, E.M., London, S., Manni, J.J., Maugard, C.M., Morita, S., Nazar-Stewart, V., Noda, K., Oda, Y., Parl, F.F., Pastorelli, R., Persson, I., Peters, W.H., Rannug, A., Rebbeck, T., Risch, A., Roelandt, L., Romkes, M., Ryberg, D., SAlagovic, J., Schoket, B., Seidegard, J., Shields, P.G., Sim, E., Sinnet, D., Strange, R.C., StüCKer, I., Sugimura, H., To-Figueras, J., VineIS, P., YU, M.C., TAIOLI, E. (2001): Metabolic gene polymorphism frequencies in control populations. Cancer epidemiology, Biomarkers \& Prevention 10 (12): 12391248 .

[13] Gerenova, J., Gadjeva, V. (2007): Oxidative stress and antioxidant enzyme activities in patients with Hashimoto's thyroditis. Comparative Clinical Pathology 16 (4): 259264. doi: 10.1007/s00580-007-0689-8

[14] Gough, S.C., Simmonds, M.J. (2007): The HLA region and autoimmune disease: associations and mechanisms of action. Current Genomics 8 (7): 453-465. doi: $10.2174 / 138920207783591690$

[15] HaQ, M., HARMER, C. (2004): Thyroid cancer: an overview. Nuclear Medicine Communications 25 (9): 861-867.

[16] Hayes, J.D., Flanagan, J.U., Jowsey, I.R. (2005): Glutathione transferases. Annual Review of Pharmacology and Toxicology 45: 51-88. doi: 10.1146/annurev.pharmtox.45.120403.095857

[17] LEe, Y.H., SEO, Y.H., KIM, J.H., CHOI, S.J., Ji, J.D., SoNG, G.G. (2015): Meta-analysis of associations between MTHFR and GST polymorphisms and susceptibility to multiple sclerosis. Neurological Sciences 36 (11): 2089-2096. doi: 10.1007/s10072-015-2318-7

[18] Mann, C.L., Davies, M.B., Boggild, M.D., Alldersea, J., Fryer, A.A., Jones, P.W., Ko Ko, C., Young, C., Strange, R.C., Hawkins, C.P. (2000): Glutathione Stransferase polymorphisms in MS: their relationship to disability. Neurology 8 (3): 552557.

[19] Milošević-Djordjević, O., Grujičić, D., Radović-Jakovljević, M., Marinković, D., Dimitrijević, S., Mihaljević, O., Mijatović-Teodorović, LJ., ŽivančevićSIMONOVIĆ S. (2017): Influence of GSTT1 and GSTM1 null genotypes on differentiated 
thyroid cancer risk and baseline and radioiodine induced cytogenetic damage in peripheral blood lymphocytes of patients. Genetika 49 (2): 599-611.

doi: 10.2298/GENSR1702599M

[20] OHL, K., Tenbrock, K., KIPP, M. (2016): Oxidative stress in multiple sclerosis: Central and peripheral mode of action. Experimental Neurology 277: 58-67. doi: 10.1016/j.expneurol.2015.11.010

[21] Pender, M.P., Greer, J.M. (2007): Immunology of multiple sclerosis. Current Allergy and Asthma Reports 7 (4): 285-292. doi: 10.1007/s11882-007-0043-X

[22] Ray, S., Sonthalia, N., Kundu, S., Ganguly, S. (2012): Autoimmune Disorders: An Overview of Molecular and Cellular Basis in Today's Perspective. Journal of Clinical \& Cellular Immunology S10:003. doi: 10.4172/2155-9899.S10-003

[23] RIEGER, R., GERSHWIN, M.E. (2007): The X and why of xenobiotics in primary biliary cirrhosis. Journal of Autoimmunity 28 (2-3): 76-84. doi: 10.1016/j.jaut.2007.02.003

[24] Sheenan, D., Meade, G., Foley, V.M., Dowd, C.A. (2001): Structure, function, and evolution of glutathione transferases: implications for classification of non-mammalian members of an ancient enzyme superfamily. Biochemical Journal 360 (Pt 1): 1-16.

[25] Stavropoulou, C., Korakaki, D., Rigana, H., Voutsinas, G., Polyzoi, M., Georgakakos, V.N., Manola, K.N., Karageorgiou, C.E., Sambani, C. (2007): Glutathione-S-transferase T1 and M1 gene polymorphisms in Greek patients with multiple sclerosis: a pilot study. European Journal of Neurology 14 (5): 572-574. doi: 10.1111/j.1468-1331.2006.01678.x

[26] Stošić, I., Grujičić, D., Arsenijević, S., Brkić, M., MilošEvić-Djordjević, O. (2014): Glutathione S-transferase T1 and M1 polymorphisms and risk of uterine cervical lesions in women from central Serbia. Asian Pacific Journal of Cancer Prevention 15: 3201-3205. doi: 10.7314/APJCP.2014.15.7.3201

[27] Tasset, I., Agüera, E., SÁnchez-López, F., Feijóo, M., Giraldo, A.I., Cruz, A.H., GAscón, F., TÚNEZ, I. (2012): Peripheral Oxidative Stress in Relapsing-Remitting Multiple Sclerosis. Clinical biochemistry 45 (6): 440-444.

doi: 10.1016/j.clinbiochem.2012.01.023

[28] West, I.C. (2000): Radical and oxidative stress in diabetes. Diabetic Medicine 17 (3): 171-180. doi: 10.1046/j.1464-5491.2000.00259.x

[29] Žıvković, M., Žıvotić, I., Dinčıć, E., Stojković, L., Vojinović, S., STAnković, A. (2013): The glutathione S-transferase T1 deletion is associated with susceptibility to multiple sclerosis. Journal of the Neurological Sciences 15 (1-2): 6-9. doi: 10.1016/j.jns.2013.07.001 